\title{
The Role of Knowledge in the Evolution of the Religious Phenomenon
}

\author{
Lucian Ionel Mercea
}

\begin{abstract}
In the development of the religious phenomenon, knowledge bears an essential role. The present study analyses the factors that have contributed to the emergence and the spreading of Neo-Protestant denominations (Baptist, Adventists, Brethren and Pentecostals) within the borders of Romania in the second half of the $19^{\text {th }}$ and the beginning of the $20^{\text {th }}$ century. Four different perspectives are presented: the orthodox, communist, neo-Protestant and sociological points of view. With this paper we will observe the way knowledge played an important role in the appearance and development of neo-Protestant confessions in Romania. That mainstream churches in Romanian (Orthodox, Catholic), preoccupied more with the ritualistic aspects of their liturgical services, didn't fulfill the needs of believers in search for a deeper spiritual experience. For this to occur, believers belonging to these ecclesiastical traditions have turned towards what has been labeled neo-Protestantism in Romania.

KEY WORDS: knowledge, neo-Protestant, Baptist, Adventists, Brethren, Pentecostals, orthodox.
\end{abstract}

\section{Introduction}

In the development of the religious phenomenon, knowledge bears 1 an essential role. Changes incurred in the field of knowledge influence the religious phenomenon and its development. Those religions that do not adjust and don't keep up to the dynamics of 
knowledge are meant to perish and disappear. With this paper we will observe the way knowledge played an important role in the appearance and development of neo-Protestant confessions in Romania, especially in the regions in Transylvania and Banat.

Until this moment, there is no objective and scientific study related to the causes that determined and facilitated the penetration of neo-Protestant confessions in Banat and Transylvania. Both the interwar studies and the communist ones have had a pragmatic feature, to fight against and discredit them.

The most numerous category of researchers comes from the Orthodox clergy. Thus, various books and brochures were printed, articles were published in the news of those times, the public authorities and the Romanian society being warned about the danger related to the "sects", regarding the national security and security of the Romanian religion. ${ }^{1}$ Here are analyzed some causes that relate to the appearance and the spreading of the neo-Protestant confessions, from the perspective of the orthodox clergy, of some protestant and neo-Protestant authors, as well of some Romanian sociologists and editorialists.

\section{The Protestant Reform}

Unlike Moldova and the Romanian Country, the echoes of the protestant reform were more powerful in Transylvania and Banat. Under the ruling of Ioan Sigismund (1546-1571). ${ }^{2}$ Dieta has known the Lutheranism, Calvinism and Unitarianism. ${ }^{3}$ The presence of Anabaptists is given to us since 1527 by King Ferdinand of Austria, a devout Catholic, who complained about Hungary and Transylvania "that the Anabaptists are gaining ground." ${ }^{4}$ One century later the Anabaptists being persecuted in Boemia and Moravia, they would have a mass retreat in Transylvania, where they founded settlements such as the one from Vințul de Jos. ${ }^{5}$

The first neo-Protestants from Transylvania and Banat rose from the protestants. In 1871, a German Baptist from Vienna, named Anton Novak, employee of the British Biblical Company to distribute bibles in Hungary and Transylvania has reached Salonta Mare, where 
he meets, at the house of Janos Lajos, a group of Bible researching people. All of them were members of the reformed church of that locality, "but were not contented with the spiritual state of the church." ${ }^{6}$ Eight of them will be baptized and will establish the first neo-Protestant Church in Transylvania and Banat.

Withal, the first Adventists baptized in Arad would also derive from the Protestants. In 1895 in Arad was a group of Nazarenes, converted to Adventism by a certain Tențeși from Brașov. The latter brings the German pastor Konradi to Arad, to baptize the first group of 15 people. ${ }^{7}$ Subsequently, Adventism would develop more in villages where baptism was stronger, the Adventist members being recruited mostly within the former Baptists. ${ }^{8}$

\section{The Internal Crisis of the Orthodox Church}

The superstitions and the legacy of the pagan customs that the church did not eliminate completely, kept it far from the cultural novelties and the scientific progress of the last centuries. This was noticed by a series of influential people of the era.

In Transylvania Octavian Goga wrote that "some of the new priests started here, part lacking the cultural progress, part lacking the awareness of their dignity, a true business, which benefits financially from the spiritual weakness of peasants ... such that here too, in the depressed villages, at the foot of the mountains are still found, to this day, priests making a good earning from "taking out the devils," from the "clothes ceremony," from the "black ceremony" and other several sorceries. Some go beyond and create all sorts of fantasies, meant to slave the lack of skill of the peasant. Some tin plates, painted with saints, wrapped in a dirty cover offer the "cure" meant to "treat all illnesses." Such, Easter related objects are made, that tell all the fortune and the "wheel of fortune" telling the zodiac signs and all the secrets of the future. Such crafts are endless and their ingenuity, as is ugly, is as complicated. The peasant clean at heart believes them and heavily spends on such crafts whenever trouble occurs. There are some priests whose fame reached far in 
a corner of the country and tormented people from everywhere swarm around him, with money and victuals." 9

As illiteracy went down and the Bibles printed by the British Biblical Company were spread, there discrepancies between traditions and the Bible became more and more obvious. In 1908 Octavian Goga reclaimed that "the church has had, up to about 10 years ago, a great lack of priests and schoolteachers. According to all signs-in a brief time even the weakest parishes will be occupied, where you couldn't find a man walking with a lighted lamp the whole evening." ${ }^{10}$ The lack of clergy from the end of the $19^{\text {th }}$ century facilitated the penetration of the neo-Protestant confessions in Transylvania and Banat.

The Union in 1918 brought profound changes in the Romanian society. A spirit of independence moves the peasants, the masses were pulled out of their traditional passivity, the minister of cults of those times, Octavian Goga, stated that "the questions went down to the religious belief of our villages, shaking the supreme moral factor of the crowd, either through tenebrous mystical tendencies, either through tendencies of unexpected rationalism ... around our countryside small churches powerful attacks are given, their old walls seem to be weakened, the old Christian ideology is subject to hasty revisions." 11 The result of these assaults consists in the "extraordinary efflorescence of the sects, with tens and hundreds of thousands of followers that rose throughout the country in the late years, thanks to this moral tornado, intensified by the weakness of the church body and fueled by foreign cloudy agitation, hard to follow in their origin."12

To this state of affairs, the status of the superior clergy is added, which has "lost the historic significance, the inferior one fighting poverty and lack of skill, while the monasteries became dwellings for crippled and night shelters. From the top to the bottom brutal ignorance was settled, the church fully sacrificed the spiritual feature, the pulpit stayed inexistent, the cultural purpose was annihilated, holding, on behalf of the orphan settlement only the representative attributions, the ritualistic prescriptions."13

Another radiography of the status of the orthodox church in Transylvania is made by a clergy which underlined that the neo- 
Protestant movements, under the reason of a moral supremacy, "invaded the Romanian Orthodoxism, due to the fact that they found a field favorable for the religious formalism and the lack related to evangelical living. We must acknowledge that we became stiff in form and that we abandoned the moral living."14

This voice is not a singular one. The same orthodox clergy supports his conclusions with the statements of other orthodox clergy: "there are voice that often and rightfully rise, that say that the sects do not represent a hazard, but our weak Christian, ecclesiastical status. To the diocesan gatherings in Cluj, the priests Sava and Antal have shown that the evil is among us, not the foreign sects undermine our church, but the sect of indifference within the church itself, our formalism and our non-evangelical living." 15

The clergy itself had a poor image. The magazine "Our country" stated that "in the media there are findings, some of the most evil ones, regarding the paralysis that hit the clergy and the rottenness seen in the hollow body of the church organism." 16

In the same article, Octavian Goga was quoted with the following findings: "Our church these days is controlled by a paralyzing inertia. ... Our voiceless clergy, lacking any passion for religious truth, gave us a peasantry full of superstitions and an immoral and pagan class of intellectuals.... With a soul overcome with sadness, I am thinking about Christ and the church."17 The priest Gala Galaction is also quoted here, with the following finding: "The fact that the priest Tudor left is a first victory of Protestantism and the beginning of pains.... We are in the eve of our confessional shipwreck."18

About the clergy of the Orthodox Church, Tudor Arghezi would write "the church and the clergy and in particular the clergy, which indeed, let's not vacillate, the people do not know why he should respect."19 The bishop of Arad, Grigore Comșa seizes certain aspects meant to alienate people from orthodoxy and certain cases when "ecclesiastical persons made arrangements with the parishioners for the payment of divine services. Nothing more wrong than such an act. The priest's prestige is lost in such a case. Then, it is known that some persons, for private interests, are absent from their job for a long time, with no appropriate justification." ${ }^{20}$ 
The Orthodox Church from Ardeal was going through a major crisis, fact recognized by great personalities in the interwar period. It was written, about the status in Ardeal: "Used to watch with our eyes opened, we can see the church struggling in the way it does. We see that after a while, the priests in Ardeal are leaving it, as a ship that's stuck, saving themselves as they can on the boats of civil careers... It's been a while since we are convicted that our church is about to pass through a painful crisis. It not renewed from its fundament, if it does not change its face for the better, its iconostasis threatens to fall." 21

Tudor Arghezi is very direct in identifying the reasons why the neo-Protestant confessions appeared and spread, describing the situation as follows: "Before the prelates from the category of bourgeois enriched at the counter, obese, dull, with rich furs full of moths, the sectarian comes out lively, fiery and quick. This was not registered in the Budget, is not protected by any law, does not have a guaranteed old age, there are no whispers or rumors on his behalf. He comes in the name of a Christ meant to guide, in love with the pains of the social individual, with no sable, no car, no episcopate, no prestige, as a Christ desired by everyone. The sectarian has the relatively easy task: he always wins and focuses the sympathies of the Christians disgusted with the nouveau riche ecclesiastical organization. And the Romanian church, of our ancestors, must be protected by the police and commissaries, so that its lascivious grandeur is not broken."22

\section{The Isolation Politics Fought Against the Orthodox Church}

After the revolution in 1848, the Hungarian government lead a wide politics to turn Romanians to Hungary, meant to diminish all that was Romanian identity. Orthodoxy was seen as a bastion of the Romanian national identity, that's why it couldn't pass untouched in this ideological conflict. This was also underlined by Grigorie Comșa, orthodox bishop of Arad, who wrote that "in the beginning, the Hungarians did not see Baptism as a good thing, but after seeing 
that it spreads among Romanians, they began to support it. Even the Hungarian Baptist historian Attila Csopják admits that the government of Coloman Tisza, which hated Romanians, began to favor the Baptists. In 1892 even the Hungarian deputy Irányi Dániel spoke in the Hungarian parliament, and he said that the Baptists are good patriots." 23

These conclusions were also fueled by the statements of several Hungarian politicians. The Hungarian deputy Almay stated, in 1913, in Hungarian newspaper in Arad: "the Romanian national matter should be untied, so that the Romanian people is freed from the direction of Romanian priests. It is of great meaning that the Romanian matter, at least part of it, may be untied aided by Baptism. Baptism may reach unbelievable conquests in the county of Arad. I think this is of great meaning, because that's how the Romanian people are freed from the direction of the fanatic priests. Baptists are tolerant and live in piece with the Hungarians." ${ }^{24}$

After 1918, the state was often accused that it abdicated from the spiritual primate of orthodox religion, being too permissive to the sects, granting them the right to association, propaganda, to build worship dwellings, to establish own schools, to purchase assets. ${ }^{25}$

Some political parties that favored the Baptists were also accused. Bishop Grigorie Comșa stated that „I would call a traitor of country and nation that Romanian minister that would dare to acknowledge the Baptists. Today they are a simple association, meant to perish and not meant to be advanced to the degree of cult." 26 The church considered itself weakened due to the state policy and thus was not able anymore to face the danger represented by sects.

\section{Foreign Interference}

"Sects" were classified according to their origin, in western sects (Adventist, Baptists, Evangelicals, Pentecostals, students of the Bible, Nazarenes) that got spread from Germany, U.S.A., and oriental sects (Lipovans, Inochentists, Adepts from Scapeți, Molokans) that spread in Russia and Bulgaria. ${ }^{27}$ 
Some historians highlighted the thesis that on Romanian territory no "sect weed" was developed, because it was not auspicious to sects and the inland sects was the results of foreign influences. ${ }^{28}$ Tudor Popescu is only seen as historian founder of tudorism, and not as ideological founder himself.

The bishop Grigorie Comșa brought the most arguments for holding the theory of foreigners conspiracy, being a prolific writer on this subject. He underlined the tendency of the Hungarian nation to divide the Romanian people, showing that baptism was used as a mean to turn Romanians to Hungary, ${ }^{29}$ stating that Hungarians were the first propagandists among the people of Ardeal. ${ }^{30}$ Baptisms becomes so an enemy of the country, because "the country is one with the church."31

The same conspiratorial tendency comes out of the statement of the same bishop, which says that the "bayonet of the Hungarian virago protects the Hungarian propagandist and the Romanian can't say a thing." ${ }^{2}$ It is noted that baptism was spread in the counties that neighbor Hungary "because Hungarian had all the interest in helping the Baptism spread amongst Romanians. In the county of Bihor there are 3600 souls, in the county of Arad 6250 souls, and in the county of Caraș-Severin 2080 Baptists." ${ }^{33}$ In the "Universul" newspaper, the places in Transylvania and Basarabia where Baptism has penetrated were listed, highlighting the fact that this belief was spread mostly in the region where Romanians lived and very few in the Hungarian counties, the purpose being to enslave the Romanian population. ${ }^{34}$ Another newspaper published that "the propaganda of the sects is a thousand times more dangerous than the communist propaganda." ${ }^{35}$ Such, the foreign baptism "rushed in these Romanian territories such as grasshoppers," "fighting against national interests." ${ }^{36}$ According to these opinions Baptists "do not incite the Hungarian people, nor the French or German one so that they leave their priests. Baptists are set on the head of us, Romanians." ${ }^{37}$

Even if the tendency of Hungarian authorities was obvious, to use the activity of the neo-Protestant confessions to strengthen the Hungarian element, that's not what is found in the politics of the neo-Protestant confessions. The Hungarian authorities were solely the beneficiaries of a political and religious circumstance 
of that time, the neo-Protestant confessions being active in the same manner both among Hungarians, Germans and Romanians. Withal on the territory of our country several missionaries that came from countries that had no direct political interest over the Romanian population were active, missionaries from countries such as Switzerland, U.S.A., Germany, France etc.

The alarm given by the orthodox church related to the danger of neo-Protestants for the unity of the nation would have the purpose of determining the Romanian state to take the most severe measures in order to annihilate these "sects," by creating a psychosis among the population ${ }^{38}$ towards the danger of the "sects," the bishop Comșa stating that "I would call a traitor of country and nation that Romanian minister that would dare to acknowledge the Baptists." 39

Still foreign interference is considered the financial aid received by neo-Protestants to grant wages to those spending most of their time for the mission, for preaching and organizing. Related to this state, it was written about Baptists: "they admitted, at the Baptist congress in Arad from October 1930 that they receive money from America to pay their preachers, those who got rid of the coat and pants to wear a collar and tie and ironed pants." 40 The same author states: "it is no secret today that dollars, and other foreign money, are used to spare souls." 41

Sometimes the external interference was due precisely to the abuses committed against neo-Protestants and consisted in information and monitoring, and in case of severe breach in interventions on a high level, diplomatically. For example, in 1924 during 3-9 December, in the U.S.A. was organized a congress of all American protestant and neo-Protestant churches, gathering 28 confessions. This congress also got care of the situation of religious minorities in the European Orient. There, underlines Grigorie Comșa "amongst others, spoke: Dr. Sch?ffer and Dr. Beatsch, who in the summer of last year were in our country and studied the situation of the religious minorities from our country." 42 


\section{Analphabetism}

Analphabetism was considered by most sectarians as being one of the most important causes as far as the appearance and the spread of the new religious movements are concerned. The lack of elementary religious training is present not only in the mass of simple country believers, but also among the intellectuals of the high class society. Many attributed to the Bible and faith the saying "believe, and do not research!"43 When such individuals took contact to a connoisseur of religious teachings or of the cult they could be easily convinced to accept new teachings. ${ }^{44}$

According to an official statistic of the time, in 1908 from a total of 2.799.479 Romanians, who were found in Hungarian borders, 2.213.947 were analphabets. The worse situation was for the Romanians in Transylvania, followed by the ones in Banat. ${ }^{45}$

\section{Religious Ignorance}

A feature of the neo-Protestant religious movements was granting a fundamental role to the Bible, seeking that the life of belief is ruled by it. ${ }^{46}$ Enlightenment and French revolution brought important changes in thinking and in society. The new orientation was towards a rational religion, being in conflict with the mysticism of the traditional Christian religions.

This lack of acknowledgement of the Bible itself was recognized by a list of authors that underlined the lacks of orthodox believers in knowing the Bible: "We cannot silence ot poverty in the biblical spirit. We do not have the skill of the biblical study, nor to interpret the biblical texts. We have secondary schools and universities with studies about the Bible, without the study of the Bible. The Bible was printed in several editions ,but we are not using it. In primary and secondary school religion is taught, without the Bible. Nobody consults the Bible at the faculty of Theology, except as philological manual. The church preaches without the Bible. Too much theology; 
too little Bible. There is nowhere a chair of biblical lectures, of practical interpretation." 47

While it was admitted that the Bible is the compass of spiritual life it was found that people were alienated from the teachings of this spring of universal and supernatural moral: "That's why the believer chases the springs of biblical truth, out of which he got no taste. In other words, the Romanian is not chasing the sectarians, but the spiritual flavor, that is the Bible." 48

\section{Wars and Social Crisis}

The two world wars have determined a great thirst of the biblical teachings, but the church was not ready to fulfill this need, which got direction in the new religions. ${ }^{49}$ On the ground of some people discontent and of the economic crisis, new religious beliefs were developed. ${ }^{50}$ The ones already existent Baptists, Adventists, Evangelicals) were developed and new ones were created (Pentecostals).

The neo-Protestant confessions fructified the hard situation after the war was ended, such as: lack of housing, jobs inflation, food crisis due to drought. The army Intelligence service discovered that 20 Adventist children from Matca, county of Tecuci, were sent to be supported by the Adventists from the county of Arad. At the same time, the latter offered 50 kilograms of corn to each member of the above said confession that stayed in the county of Tecuci, being credited in the area the idea that the Adventists grant help to all those that join them. ${ }^{51}$

Withal, war was the place where soldiers from various places were reunited. The neo-Protestant believers spread their belief to the fighting colleagues and in front of the imminence of death several promised that they if they will get out alive, they will get baptized as well. Some, when returning from the battle, kept their word, they looked for the neo-Protestants (repented-as all neo-Protestants were called) and asked to be baptized. The bishop Grigore Comșa said that: "the soldiers got contact to foreigners during the war

where they caught heresies." ${ }^{2}$ 
Also, the social movements generated a climate favorable to new beliefs. The same bishop noted that after the peasants movement in 1907 Adventism spread much faster. ${ }^{53}$ The wars contributed to the awakening of many from the spiritual routine in which they were, being more sensitive to the callings and insistences of neo-Protestants. These wars lead to a climate of un-rested waiting for the end of the world. On this ground, the neo-Protestant belief became more accessible, gaining more and more ground.

It is an ascertained fact that religious movements prosper in times of crisis. World wars and economic crisis that accompanied them may be part of the explanation related to the role of external factors, which corroborated with other factors, lead to the more and more spread of neo-Protestant confessions.

\section{Emigration to the United States of America}

The last part of the 19th century and the beginning of the 20th century registered an exodus of emigrants from Transylvania and Banat to the United States. Monthly, statistics shown that thousands of citizens emigrate towards the American continent. In 3rd June 1907 the newspaper "Our country" stated that "last week alone 4.049 individuals left our country." ${ }^{4}$ Several weeks later, the same periodical would state that "last week, 2667 individuals left our country, to go to America" 55 and on the week 7-14 October another 2627 people. $^{56}$

Not even after the Great Union, the situation from Transylvania and Banat improved. It was said that the "population of the mountains, impoverished and exploited by all, tried to leave its home and emigrate to America." ${ }^{57}$ The Minister of Interior of the time, Octavian Goga, noted that "but the Romanian from Transylvania, the emigrant, has a particular psychology. He does not go there to be displaced definitively and become an American citizen. ${ }^{58}$ Most of these emigrants returned to Transylvania, and once returned to the country they brought with them the new neo-Protestant beliefs that they knew and embraced abroad. That's how many of the emigrants 
who left with the orthodox belief in their souls would come back baptized in neo-Protestant confessions.

This emigration process would be braked after 1924, and we find this in the same speech of Octavian Goga "we will not encourage an emigration process, that is why the past, as well as the new government have stopped the emigrations, no more passports for America are being granted. Under our government this exodus of the people from Ardeal has stopped."59

\section{The Appealing Feature of the New Religious Sects}

Neo-Protestants got noted due to the fact that some, who helped the citizens in various circumstances, fires, natural calamities, disease, poverty.$^{60}$ For example, in a radiogram deciphered, destined to the Council of Ministers, the attention was drawn towards a truck under American pavilion, with a load of 200 food boxes sent by the Bucharest Adventist Christian committee and distributed in the country to the poor Adventist believers on the $10^{\text {th }}$ of October $1947 .{ }^{61}$ Such situations found at neo-Protestants are numerous.

Another reason invoked by the pretor of Balinț in the letter n. 949/1939 to the prefect of the county of Severin is that "some inhabitants justify their passing to another confession by the fact that the priests cash exaggerated amounts when rendering services to their believers according to the dogmas, such as: baptizes, marriages, funerals and so forth." 62 The neo-Protestant confessions represented, in this respect, an attraction to those who considered the amounts cashed in by the priests on the said events too high.

Numerous authors refer to foreign help granted to neoProtestants through missionaries from the Occident. The bishop Comșa gave concrete examples in this respect: "Baptists receive intense help from America from where three Baptist agents arrived in the country, American citizens. In the French journal Semailles et Moisson from October 1925, the new that the gatherings of the Swiss brothers support evangelists in Brașov and Iași was published." 63

Other times, there were references to the foreign material help granted to them ${ }^{64}$ or to the external political interventions in 
favor of religious freedom for neo-Protestants. The neo-Protestant beliefs have drawn people through the simplicity of the belief. ${ }^{65}$ This simplicity was obvious both liturgical ${ }^{66}$ as well as in the improvement of the cult dwellings. These were usually placed in the center of the localities, close to some institutions, having on the bas-relief on the front the form of a cross. ${ }^{67}$ Neo-Protestants preached a safer and faster way to salvation. ${ }^{68}$

Withal, the familiar environment of the neo-Protestant communities was considered another factor that contributed to their development. It was said that they set the grounds of small communities, where they can establish close relationships, of sharing, getting closer to each other and knowing each other, remembering the first gatherings of the primary Christian church, based on the family religious communion. ${ }^{69}$ Another activator of the neo-Protestant confessions is represented by the religious enthusiasms manifested through a religiosity considered excessive (preaches full of pathos, joint singing, choirs, orchestra, brass band, soloist, reciter),$^{70}$ courtesy towards visitors.

To this factor, the priority to the living of the belief is added, fact underlined by various authors: "Sects make out of religion their internal world and the only world true to each believer, so that religion reaches the first plan in their thinking, feeling and goals. In any circumstance, in any issue, their belief and their religious duty overcomes everything." 71

An appealing fact of the neo-Protestant confessions was represented by the "democratic" aspects in organizing and the practice of the cult. The neo-Protestant confessions promoted ideas so appealing related to freedom, brotherhood and equality transposing them in the religious field. ${ }^{72}$

The organizing structure of the neo-Protestant confessions made them more capable in fulfilling their mission and in answering the challenges. They were organized fast and spontaneously, always adjusting to changes.

Through the congregational organization there was the possibility to actively participate to the life and direction of the community. The members participated to talks, they were listened, their opinion was taken into account, their leaders were also elected 
through vote and periodically assessed by the majority. This way, neo-Protestants are closer to the democratic principles and to religious pluralism. ${ }^{73}$

The missionary activity and canvassing were the instruments with which the neo-Protestant confessions entered in new territories. They used a rich literature, with appealing titles and subjects, such awakening interest and curiosity.

\section{Conclusion}

Most sociologists and researchers of the neo-Protestant phenomenon consider that the so called "sects" blamed so much and rejected since they appeared are both the result and the product of certain social requirements and correspond to a spiritual religious need. It is a reality that must be accepted the one that most of the churches left by the believers no longer reach their religious aspiration and the hope for redemption. This provided, religious movements are born, that through their messages re-launch hope, suggest new ideals.

In a cold, hostile world, indifferent to the inner, human needs, damaged by violence, wars, uncertainty, historical "sects" offer a new spiritual, unitary and novel direction. ${ }^{74}$ They represent, with human reductions and imperfections, a viable alternative for those wanting a more intense, more profound religious living, opening new horizons of knowledge.

NOTES

${ }^{1}$ Gheorghe Modoran, Apariția și răspândirea confesiunilor neoprotestante în România, in "TheoRhēma" vol. 2 n. 2, (Cernica: Editura Institutului Teologic Aventist, 2007), 103.

${ }^{2}$ Ioan-Gheorghe Rotaru, Sabatarienii în contextul vieții transilvane (sec. XVI-XIX), Vol. I. (Cluj-Napoca: Editura Risoprint, 2014), 216-264.

${ }^{3}$ Alexa Popovici, Istoria anabaptiștilor din România 1527-1768, (Oradea: Făclia, 2009), 27.

${ }^{4}$ C.C. Giurescu, Istoria Românilor, II, Partea întâia, Vol I, (București, 1940), 329 Ioan-Gheorghe Rotaru, Sabatarienii în contextul vieții transilvane (sec. XVIXIX), Vol. I. (Cluj-Napoca: Editura Risoprint, 2014), 382-383. 
${ }^{5}$ Kirner A. Bertalan, Baptista Kronika, (Budapest, 1935), 110-111. IoanGheorghe Rotaru, Sabbatarians in the context of life in Transylvania (centuries XVI-XIX), Vol. I. (Cluj-Napoca: Risoprint Publishing House, 2014, 2014), 542544.

${ }^{6}$ Alexa Popovici, Istoria baptiștilor din România 1856-1989, (Oradea: Făclia, 2007), 30.

${ }^{7}$ Arhivele Consiliului National pentru Studierea Arhivelor Securității

(A.C.N.S.A.S), Documentary Fund, file n. 16563, 2.

${ }^{8}$ Ibid, 1.

9 Octavian Goga, Vrem calea adevărului, in "Țara noastră," anul I, nr. 43, (Sibiu : 1907), 696-697.

${ }^{10}$ Octavian Goga, Din problemele noastre culturale, in"Țara noastră," anul II, nr. 38, (Sibiu: 1908). 276.

${ }^{11}$ Octavian Goga, Problema religioasă, in"Țara noastră," anul III, nr.11, (Cluj:1922), 330.

12 Ibid.

${ }^{13}$ Ibid, 331.

${ }^{14}$ G.L. G.L. Botoșăneanu, Confesiuni și secte - studiu istorico misionar, (București: Tipografia Cărților Bisericești, 1929), 206.

${ }^{15}$ Ibid, 207.

${ }^{16}$ Grigore Mireanu, Criza bisericească, in"Țara noastră," anul V, nr. 8, (Cluj: 1924), 233.

${ }^{17}$ Ibid.

${ }^{18}$ Ibid, 234.

${ }^{19}$ Tudor Arghezi, Epistolă către preoți, in "Țara noastră," anul VII, nr.33, (Cluj:1926), 938.

${ }^{20}$ Gheorghe Comșa, Pentru slujitorii altarului - meditații și îndemnuri, (Caransebeș: Tiparul Tipografiei Diecezane, 1925), 10-11.

${ }^{21}$ Grigore Mireanu, Criza bisericească, in "Țara noastră," anul V, nr. 8, (Cluj: 1924), 234.

${ }^{22}$ Tudor Arghezi, Epistolă către preoți, in "Țara noastră," anul VII, nr. 33, (Cluj:1926), 939.

${ }^{23}$ Grigorie Gh. Comșa, Baptismul în România din punct de vedere istoric, național și religios, (Arad: Tiparul Tipografiei Diecezane, 1927), 22.

${ }^{24}$ Aradi Közlöny, 25 December (Arad: 1913).

${ }^{25}$ Gheorghe Modoran, Apariția și răspândirea confesiunilor neoprotestante în România, in "TheoRhēma" vol. 2 n. 2, (Cernica: Editura Institutului Teologic Aventist, 2007), 116.

${ }^{26}$ Grigorie Gh. Comșa, Baptismul în România din punct de vedere istoric, național și religios, (Arad: Tiparul Tipografiei Diecezane, 1927), 72.

${ }^{27}$ Gheorghe Modoran, Apariția și răspândirea confesiunilor neoprotestante în România, in "TheoRhēma" vol. 2 n. 2, (Cernica: Editura Institutului Teologic Aventist, 2007), 116. 
28 Cornel Sârbu, Originea și răspândirea sectarismului, (Sibiu: Tiparul Tipografiei Arhidiecezane, 1945),35-36.

${ }^{29}$ Grigorie Comșa, Noua călăuză pentru cunoașterea și combaterea sectelor religioase, (Arad: Tiparul Tipografiei Diocezane, 1922), 50.

${ }^{30}$ Grigorie Gh. Comșa, Baptismul în România din punct de vedere istoric, național și religios, (Arad: Tiparul Tipografiei Diecezane, 1927), 14.

${ }^{31}$ Ibid, 43.

32 Ibid, 15-16.

${ }^{33}$ Gheorghe Comșa, Călăuza cunoașterii și combaterii sectelor, (Cernica: Tipografia Bisericească, 1925), 39-40.

34 "Universul," 26 februarie 1927.

35 "Cuvântul," 2 aprilie 1926.

${ }^{36}$ Grigorie Gh. Comșa, Baptismul în România din punct de vedere istoric, național și religios, (Arad: Tiparul Tipografiei Diecezane, 1927), 40

${ }^{37}$ Grigorie Comșa, Lupta baptiștilor împotriva preoțimii Române, (Arad, Tiparul Tipografiei Diecezane, 1925), 3.

${ }^{38}$ Gheorghe Modoran, Apariția și răspândirea confesiunilor neoprotestante în România, in "TheoRhēma" vol. 2 n. 2, (Cernica: Editura Institutului Teologic Aventist, 2007), 110.

${ }^{39}$ Grigorie Gh. Comșa, Baptismul în România din punct de vedere istoric, național și religios, (Arad: Tiparul Tipografiei Diecezane, 1927), 72.

${ }^{40}$ Grigorie Gh. Comșa, Cenușa de pe capul baptiștilor, (Arad: Tiparul Tipografiei Diecezane, 1931), 4.

${ }^{41}$ Gheorghe Comșa, Călăuza cunoașterii și combaterii sectelor, (Cernica: Tipografia Bisericească, 1925), 7.

${ }^{42}$ Gheorghe Comșa, Pentru slujitorii altarului-meditații și îndemnuri, (Caransebeș: Tiparul Tipografiei Diecezane, 1925), 7.

${ }^{43}$ Gheorghe Modoran, Apariția și răspândirea confesiunilor neoprotestante în România, in "TheoRhēma" vol. 2 n. 2, (Cernica: Editura Institutului Teologic Aventist, 2007), 111.

${ }^{44}$ Alexandru Scvoznicov, Psihologia sectelor religioase,(Chișinău: Monitorul Oficial și Imprimeriile Statului, 1939), 10.

45 Țara noastră, anul II, nr. 11, (Sibiu: 1908, 11.

${ }^{46}$ Gheorghe Modoran, Apariția și răspândirea confesiunilor neoprotestante în România, in "TheoRhēma" vol. 2 n. 2, (Cernica: Editura Institutului Teologic Aventist, 2007), 112.

${ }^{47}$ Marin Ionescu, Sectarismul, un mare pericol social, (București: Tipografia Carpați, 1941), 39.

48 Ibid, 17. Pavel Nicoară, Rătăciri pe aceeași cale falsă, (București: Societatea pentru Răspândirea Științei și Culturii, 1960), 41.

${ }^{49}$ Gheorghe Modoran, Apariția și răspândirea confesiunilor neoprotestante în România, in "TheoRhēma" vol. 2 n. 2, (Cernica: Editura Institutului Teologic Aventist, 2007), 113. 
${ }^{50}$ Alexandru-Alin Spânu, "Sectele religioase în rapoartele Serviciului de Informații ale Armatei(1947)," in Adrian Nicolae Petcu, Partidul, Securitatea și Cultele(1945-1989), (București: Nemira, 2005), 117.

${ }^{51}$ Ibid, 120.

${ }^{52}$ Gheorghe Comșa, Călăuza cunoașterii și combaterii sectelor, (Cernica: Tipografia Bisericească, 1925), 99.

${ }^{53}$ Ibid, 49.

${ }^{54}$ Țara noastră, anul I, nr. 23, (Sibiu:1907), 388.

${ }^{55}$ Țara noastră, anul I, nr. 26, (Sibiu:1907), 436.

${ }^{56}$ Țara noastră, anul I, nr. 42, (Sibiu:1907), 692.

${ }^{57}$ Ţara noastră, anul IV, nr. 29, (Cluj: 1923), 924.

${ }^{58}$ Ibid, 294.

${ }^{59}$ Ibid.

${ }^{60}$ Cornel Sârbu, Originea și răspândirea sectarismului, (Sibiu: Tiparul Tipografiei Arhidiecezane, 1945), 31.

${ }^{61}$ A.P.C.M., Intelligence Special Service, file 4/1927, 4.

${ }^{62}$ Arhivele Naționale Direcția Județeană Timiș (A.N.D.J.T.), Prefectura Județului Severin, file 26/1939, 157.

${ }^{63}$ Grigorie Comșa, Noua călăuză pentru cunoașterea și combaterea sectelor religioase, (Arad: Tiparul Tipografiei Diocezane, 1922), 116.

${ }^{64}$ Alexandru Scvoznicov, Psihologia sectelor religioase, (Chișinău: Monitorul Oficial și Imprimeriile Statului, 1939), 23.

${ }^{65}$ A.C.N.S.A.S., Documentary fund, file 141, vol. 2, 209.

${ }^{66}$ Alexandru Scvoznicov, Psihologia sectelor religioase, (Chișinău: Monitorul Oficial și Imprimeriile Statului, 1939), 37.

${ }^{67}$ A.C.N.S.A.S, Documentary Fund, file 141, vol. 2, 206.

${ }^{68}$ G.L. Botoșăneanu, Confesiuni și secte - studiu istorico misionar, (București: Tipografia Cărților Bisericești, 1929), 6.

${ }^{69}$ Cornel Sârbu, Originea și răspândirea sectarismului, (Sibiu: Tiparul Tipografiei Arhidiecezane, 1945),28.

${ }^{70}$ Gheorghe Modoran, Apariția și răspândirea confesiunilor neoprotestante în România, in "TheoRhēma" vol. 2 n. 2, (Cernica: Editura Institutului Teologic Aventist, 2007), 121.

${ }^{71}$ Pavel Nicoară, Rătăciri pe aceeași cale falsă, (București: Societatea pentru Răspândirea Științei și Culturii, 1960), 31.

${ }^{72}$ Gheorghe Modoran, Apariția și răspândirea confesiunilor neoprotestante în România, in "TheoRhēma" vol. 2 n. 2, (Cernica: Editura Institutului Teologic Aventist, 2007), 125.

${ }^{73}$ Constantin Cuciuc, Religii noi în România, (București: Editura Gnosis, 1996), 55-56.

${ }^{74}$ Gheorghe Modoran, Apariția și răspândirea confesiunilor neoprotestante în România, in "TheoRhēma" vol. 2 n. 2, (Cernica: Editura Institutului Teologic Aventist, 2007), 135. 